\title{
New data on the Oriental Xantholinini. 44. New species and new records from Nepal, Malaysia, Vietnam, Philippines, Sumatra, and Sabah

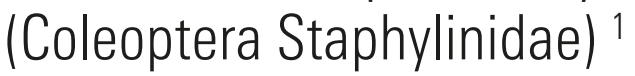

\author{
With 34 figures
}

ARnaldo BORDONI ${ }^{2}$

\author{
${ }^{2}$ Museo di Storia Naturale dell'Università, di Firenze, sezione di Zoologia "La Specola”, via Romana 17, I-50125 Firenze, Italy. \\ - arnaldo.bordoni@fastwebnet.it \\ Published on 2017-12-08 \\ DOI:10.21248/contrib.entomol.67.2.255-264'
}

\section{Abstract}

The following new species are described and illlustrated: Pachycorynus sabahensis spec. nov. (Sabah), P. balaneion spec. nov. (Sabah), P. kinabaluensis spec. nov. (Sabah), P. danum spec. nov. (Sabah), P. lanceolatus spec. nov. (Sabah), Metolinus vulcanalis spec. nov. (Sumatra), M. jubing spec. nov. (Nepal), Phacophallus philippinus spec. nov. (Philippines), and Medhiama nepalica spec. nov. (Nepal). New records of some known species are provided. Metolinus barutimus Bordoni, 2002 for Sumatra and Erymus gracilis (FAuvel, 1895) for Sabah are recorded for the first time.

\section{Nomenclatural acts}

Pachycorynus sabahensis spec. nov. - urn:lsid:zoobank.org:act:8A46B980-607F-4D0F-8D32-11DB0F4EDEFC Pachycorynus balaneion spec. nov. - urn:lsid:zoobank.org:act:47CA5C2C-68C2-4528-877E-CBF7E05FFA44 Pachycorynus kinabaluensis spec. nov. - urn:lsid:zoobank.org:act:EF8DEA6B-4C5A-4A19-B37B-286EC43E7A3E Pachycorynus danum spec. nov. - urn:lsid:zoobank.org:act:5F94A1A5-197B-4DFB-A5FB-C46F25D7F844 Pachycorynus lanceolatus spec. nov. - urn:lsid:zoobank.org:act:EB10CBEA-8DEE-42EC-A58C-585FB85078D8 Metolinus vulcanalis spec. nov. - urn:lsid:zoobank.org:act:6855264B-EFA5-414B-907C-DED6577E94DD Metolinus jubing spec. nov. - urn:lsid:zoobank.org:act:468FF7B1-8DC1-4BD2-9E49-66EA14A9F8B8 Phacophallus philippinus spec. nov. - urn:lsid:zoobank.org:act:7175C0E0-77AD-4DBA-94FC-00FA79EE61FF Medhiama nepalica spec. nov. - urn:lsid:zoobank.org:act:B8C8F894-EC9B-4EC4-BE91-30D8AD412AB

Key words

Coleoptera, Staphylinidae, new species, Nepal, Malaysia, Vietnam, Philippines, Sumatra, Sabah

\footnotetext{
${ }^{1} 282^{\circ}$ contribution to the knowledge of the Staphylinidae
} 


\section{Zusammenfassung}

Folgende neun Arten werden neu beschrieben und illustriert: Pachycorynus sabahensis spec. nov. (Sabah), P. balaneion spec. nov. (Sabah), P. kinabaluensis spec. nov. (Sabah), P. danum spec. nov. (Sabah), P. lanceolatus spec. nov. (Sabah), Metolinus vulcanalis spec. nov. (Sumatra), M. jubing spec. nov. (Nepal), Phacophallus philippinus spec. nov. (Philippines) und Medhiama nepalica spec. nov. (Nepal). Weiterhin werden für einige bekannte Arten neue Funde gemeldet, darunter zum ersten Mal Metolinus barutimus BORDONI, 2002 von Sumatra und Erymus gracilis (FAUVEL, 1895) aus Sabah.

\section{Introduction}

This contribution shows the result of the study of some material from Nepal, India, Malaysia, Sumatra, and Sabah preserved in the Naturhistorisches Museum of Basel (Switzerland), and in the collections of Yasuhiko Hayashi (Kawanishi, Japan) and Arnaldo Bordoni (Florence, Italy).

The collection of some specimens of Pachycorynus MotsCUlSky, 1858 in far fallen trees of Lithocarpus in Sabah has been particularly fruitful and allows to describe five new species. As already pointed out elsewhere (BORDONI, 2002), the species of this genus are closely related to the subcortical habitat and marshal wood, probably at different moments of decomposition of trees and perhaps different species of trees correspond to different taxa. This partly explains the rich biodiversity of the genus. The rather small size and body flatness, along with the very structural fragility of the aedeagus, make this genus the most complex to study in the tribe.

The species of the genus Pachycorynus indeed are very difficult to study for the following reasons: body usually similar in size, coloration and punctation, and aedeagus of very small size (a high magnification is required for the study), transparent and membranous and therefore difficult to read. The basal bulb is generally narrow, totally membranous and very long (not showed in the proposed figures). In the figures the measurements in millimeters refer only to the distal portion of the aedeagus. The only character that divides the species into two groups is the presence or absence of a lateral groove, behind eyes.

So far only Pachycorynus fuscoelytratus BoRdoni, 2004 occurs in Sabah (Mt. Kinabalu). The other known species of Borneo had been collected in Sarawak [P. lateralis Cameron, 1928 (Tutoh, Mt. Murud) and P. borneensis CAmeron, 1928 (Mt. Murud)]. The first is known for a single female, while the latter is known also for a male whose aedeagus is very different from that of the species here described. They differ however from the new species by coloration, large size and punctation.

\section{Acronyms}

cB coll. Bordoni, Florence, Italy

$\mathrm{cH}$ coll. Y. Hayashi, Kawanishi, Japan

cJ coll. J. Janak, Rtyne nad Bilinou, Cekia

NHMB Naturhistorisches Museum, Basel, Switzerland

\section{Taxonomy (in systematic order)}

\section{Pachycorynus rhodesianus BORDONI, 2002}

Examined material: N Vietnam, $52 \mathrm{~km} \mathrm{SW} \mathrm{Lang}$ Son, 21.35N, 106.30E, Pacholatko \& Dembicky 27.IV6.V.1996, 1 ex. (NHMB), 1 ex. (cB).

Distribution: This species was described from Vietnam (50 km NO Tain Nguien, Kui-chau, Xuan Son and Dien Bien $\mathrm{Fu}$ ). This is the first record since the description of the taxon.

\section{Pachycorynus modestus BeRnhAUER, 1928}

Examined material: N Sumatra, Brastagi, Gn. Sibayak, 1450-1900 m, Bocak \& Bocakova 19-23.II.1991, 3 exx. (NHMB), 2 exx. (cB)

Distribution: This species was described from Sumatra (Dodok). This is the first record since the single subsequent citation (7 km N Brastagi: BordONI, 2002).

\section{Pachycorynus sabahensis spec. nov. urn:Isid:zoobank.org:act:8A46B980-607F-4DOF-8D32-11DBOF4EDEFC (Figs 1-3, 28)}

Examined material: Holotype $\sigma^{\star}$ : Borneo, Sabah, Ranau, Poring H. S., $500 \mathrm{~m}$, Zhou 18.IV.2015 (cB); paratypes: same data, 2 우 (cB).

Description: Length of body $5.4 \mathrm{~mm}$; from anterior margin of head to posterior margin of elytra: about $2.7 \mathrm{~mm}$. Head with lateral groove from the posterior margin of eyes to the posterior angles of head. Body (Fig. 28) dark reddish brown, with yellowish posterior half of elytra; antennae and legs brown. Head sub-quadrangular, with sub-rectilinear and sub-parallel sides. Eyes small and not protruding. Surface of head without lateral grooves, with more or less longitudinal, fine micro-striation and some evident punctures. Pronotum shorter and narrower than head, with oblique anterior margins, rounded anterior angles and not sinuate sides. Surface with more or less horizontal microstriation and 3 series of evident punctures to the sides of a median stripe. Elytra sub-rectangular, with sub- 
rectilinear and sub-parallel sides and marked humeral angles. Surface with numerous, closed series of very fine punctures. Abdomen with fine, closed, transverse microstriation and very fine punctation.

Tergite and sternite of the male genital segment as in Figs 1-2. Aedeagus (Fig. 3) filiform, with very long and narrow, semitransparent basal bulb; distal portion $0.44 \mathrm{~mm}$ long, with acute median lobe; parameres long, arched and narrow; inner sac with series of very fine, minute scales.

Etymology: The specific epithet refers to Sabah.

Distribution: The species is known only from the type locality.

\section{Pachycorynus balaneion spec. nov. urn:Isid:zoobank.org:act:47CA5C2C-68C2-4528-877E-CBF7E05FFA44 (Figs 4-6, 29)}

Examined material: Holotype $\sigma^{\star}$ : Borneo, Sabah, Ranau, Poring H. S., 500 m, Zhou 18.IV.2015 (cB).

Description: Length of body $5 \mathrm{~mm}$; from anterior margin of head to posterior margin of elytra: about $2.5 \mathrm{~mm}$. Head with lateral groove from the posterior margin of eyes to the posterior angles of head. Body (Fig. 29) similar to that of $P$. sabahensis spec. nov. from which differs by the following characters: body smaller and narrower, elytra unicolor and narrower, proportionately longer; head with finer punctation; pronotum with finer and sparser punctation; elytra with denser punctation.

Tergite and sternite of the male genital segment as in Figs 4-5. Aedeagus (Fig. 6) with shorter basal bulb compared to that of $P$. sabahensis; distal portion $0.37 \mathrm{~mm}$ long, whit rounded apex; parameres long, significantly longer than median lobe, dilated in distal portion; inner sac with minute scales.

Etymology: The specific epithet is the Greek $\beta a \lambda a v \varepsilon ı v$ (spa bath), in relation to the local structures of hot water.

Distribution: The species is known only from the type locality.

\section{Pachycorynus kinabaluensis spec. nov. urn:Isid:zoobank.org:act:EF8DEA6B-4C5A-4A19-B37B-286EC43E7A3E (Figs 7-9, 30)}

Examined material: Holotype $\sigma^{\star}$ : Borneo, Sabah, Kinabalu Mt., Headquarters env., 1600 m, Zhou 16.IV.2015 (cB); paratypes: same data, 2 우 $(\mathrm{cB})$.

Description: Length of body $3.5 \mathrm{~mm}$; from anterior margin of head to posterior margin of elytra: about $1.8 \mathrm{~mm}$. Head without lateral grooves. Body (Fig. 30) slightly convex, light yellowish brown, with darker elytra. Head sub-rectangular, slightly longer than wide, with sub-parallel and sub-rectilinear sides and strictly rounded posterior angles. Eyes medium-sized and slightly protruding. Surface of head with polygonal microreticulation and evident, dense punctation, except of median stripe. Pronotum shorter and distinctly narrower than head, with oblique anterior margins, rounded anterior angles and slightly sinuate sides. Surface with numerous punctures, except of median stripe. Elytra very longer and wider than pronotum, sub-rectangular, with marked humeral angles. Surface with very fine, dense punctation. Abdomen with more or less polygonal microreticulation and fine, very sparse punctation.

Tergite and sternite of the male genital segment as in Figs 7-8. Aedeagus (Fig. 9) with short basal bulb; distal portion $0.33 \mathrm{~mm}$ long, with rounded apex; parameres very narrow, as long as median lobe; inner sac apparently not visible.

Etymology: The specific epithet refers to the type locality.

Distribution: The species is known only from the type locality.

Remarks: This species differs from P. fuscoelytratus Bordoni, 2004 from Kinabalu Nat. Park by a little larger body, polygonal micro-reticulation and not transverse micro-striation on abdomen, and especially by the different shapes of tergite and sternite of the male genital segment and aedeagus.

\section{Pachycorynus danum spec. nov. urn:Isid:zoobank.org:act:5F94A1A5-197B-4DFB-A5FB-C46F25D7F844 (Figs 10-12, 31)}

Examined material: Holotype $\sigma^{*}$ : Borneo, Sabah, Danum Valley, $90 \mathrm{~km}$ W Lahad Datu, $100 \mathrm{~m}$, Zhou 22.IV.2015 (cB).

Description: Length of body $3.5 \mathrm{~mm}$; from anterior margin of head to posterior margin of elytra: about $1.9 \mathrm{~mm}$. Head without lateral grooves. Similar to P. kinabaluensis spec. nov. from which differs by the following characters: body (Fig. 31) very flat, brown, with yellowish antennae and legs; head longer and narrower, with smaller eyes and very fine and sparse punctation; pronotum broader, anteriad more dilated, with more oblique anterior margins, not sinuate sides and finer, sparser punctation; elytra narrower, with finer punctation; abdomen with transverse micro-striation and fine punctation.

Tergite and sternite of the male genital segment as in Figs 10-11. Aedeagus of peculiar shape (Fig. 12) with broad and very short basal bulb; distal portion $0.25 \mathrm{~mm}$ long; parameres very narrow, shorter than the median lobe; inner sac with very minute scales. 
Etymology: The specific epithet refers to the type locality, as a noun in apposition.

Distribution: The species is known only from the type locality.

\section{Pachycorynus lanceolatus spec. nov. urn:Isid:zoobank.org:act:EB10CBEA-8DEE-42EC-A58C-585FB85078D8 (Figs 13-15, 32)}

Examined material: Holotype $\sigma^{-}$: Borneo, Sabah, Danum Valley, $90 \mathrm{~km}$ W Lahad Datu, $100 \mathrm{~m}$, Zhou 22.IV.2015 (cB).

Description: Length of body $3.5 \mathrm{~mm}$; from anterior margin of head to posterior margin of elytra: about $1.9 \mathrm{~mm}$. Head without lateral grooves. Similar to P. danum spec. nov. from which differs by the following characters: body (Fig. 32) narrower, with partially lighter posterior half of elytra; head longer and narrower, with more evident punctation; eyes larger and more protruding; pronotum longer, less dilated anteriad, with more oblique anterior margins and sparser punctation; elytra narrower.

Tergite and sternite of the male genital segment as in Figs 13-14. Aedeagus (Fig. 15) with moderately long basal bulb; distal portion small, $0.18 \mathrm{~mm}$ long, with spear shaped apex; inner sac apparently not visible.

Etymology: The specific epithet is the Latin lanceolatus (spear shaped), in relation to the shape of the apex of the median lobe.

Distribution: The species is known only from the type locality.

\section{Metolinus napalicus (CoIfFAIt, 1975)}

Examined material: Nepal, Umg. Dhumpus, b. Pokhara, Franz, $1 \sigma^{\star}(\mathrm{cB})$.

Distribution: This species is known from North India and Nepal (Bordoni, 2002).

\section{Metolinus barutimus BoRDoNI, 2002}

Examined material: N Sumatra, Brastagi, Gn. Sibayak, 1500 m, Li 18.II.2015, 1 o (cB).

Distribution: This species was described from Malaysia (Pahang, Cameron Highlands and near Tanah Rata). New record for Sumatra.

\section{Metolinus banjaraensis BoRDoNI, 2003}

Examined material: W Malaysia, Kelantanm $30 \mathrm{~km}$ NWGua Musang, Ulu Lalat Mt, 800-1000 m, Kapong Sungai OM, P. Cecovsky 27.V-19.VI.2011, 1 ơ (cJ).

\section{Distribution: Malaysia.}

Remarks: This species was described from W Perak (25 km NE Ipoh). This is the first recond since the description of the species.

\section{Metolinus vulcanalis spec. nov. urn:Isid:zoobank.org:act:6855264B-EFA5-414B-907C-DED6577E94DD (Figs 16-18, 33)}

Examined material: Holotype $o^{\top}:$ N Sumatra, Gn. Sibayak, 1500 m, Li 15.II.2015 (cB).

Description: Length of body $4.4 \mathrm{~mm}$; from anterior margin of head to posterior margin of elytra: $2.3 \mathrm{~mm}$. Small, nice species (Fig. 33), characterized by large and protruding eyes, reddish brown body, with yellowish posterior half of pronotum, long and sub-rectangular elytra. Antennae and legs yellowish. Head sub-rectangular, narrow anteriad, with rounded posterior angles. Eyes large and protruding. Surface of head shiny, with very few, evident punctures. Pronotum sub-rectangular, narrow, narrower and longer than head, with slightly oblique anterior margins, rounded anterior angles and not sinuate sides. Surface with dorsal series of 5 fine and scattered punctures and lateral series of 3 anterior punctures. Elytra sub-rectangular, not dilated posteriad, very long, longer and wider than pronotum, with conspicuous humeral angles. Surface with three series of very fine punctures, one juxtasutural, one median and one lateral. Abdomen without micro-sculpture, with fine and very sparse punctation.

Posterior margin of the sixth visible sternite with a short, median lobule. Tergite and sternite of the male genital segment as in Figs 16-17. Aedeagus (Fig. 18) $0.27 \mathrm{~mm}$ long, ovoid, with short parameres; inner sac with numerous subsequent spines.

Etymology: The specific epithet is the Latin vulcanalis- $e$, in relation to the Sibayak volcano.

Distribution: The species is known only from the type locality.

Remarks: Based on external characters the new species is close to M. heuresilogus BoRDONI, 2002 from Thailand and M. apomontis Bordoni, 2002 from the Philippines from which it is easily distinguished by the structure of the inner sac of the aedeagus. 


\section{Metolinus jubing spec. nov.}

urn:Isid:zoobank.org:act:468FF7B1-8DC1-4BD2-9E49-66EA14A9F8B8

(Figs 19-21)

Examined material: Holotype $\sigma^{\star}$ : NE Nepal, Jubing, 1300 m, I. Zhou 9.VII.2016 (cB).

Description: Length of body $4 \mathrm{~mm}$; from anterior margin of head to posterior margin of elytra: $2 \mathrm{~mm}$. Body very dark reddish brown, with light brown antennae and legs. Head sub-rectangular, slightly narrow anteriad, with sub-rectilinear sides and rounded posterior angles. Eyes small and not protruding. Surface of head with traces of transverse micro-striation and fine, sparse punctation. Pronotum sub-rectangular, longer and a little narrower than head, with sub-rectilinear and sub-parallel sides, oblique anterior margins and largely rounded anterior angles. Surface with dorsal series of 7-8 fine punctures and oblique lateral series of 5-6 punctures. Elytra sub-rectangular, not dilated posteriad, with sub-parallel and sub-rectilinear sides, slightly longer and wider than pronotum, with conspicuous humeral angles. Surface with some series of very fine and scattered punctures. Abdomen with feebly traces of fine, transverse micro-striation and fine punctation on the sides.

Posterior margin of the sixth visible tergite rounded; posterior margin of the sixth visible sternite with median emargination. Tergite and sternite of the male genital segment as in Figs 19-20. Aedeagus (Fig. 21) $0.77 \mathrm{~mm}$ long, ovoid, with acute distal lobe and very short and narrow parameres; inner sac looks like a compact mass, in fact composed of two sets of large spines located very close together.

Etymology: The specific epithet refers to the type locality, as a noun in apposition.

Distribution: The species is known only from the type locality.

Remarks: Based on the external characters this species is closely related to the gardneri-group (for details see BORDONI, 2002).

\section{Phacophallus flavipennis (KRAATZ, 1859)}

Examined material: NE India, Meghalaya, W Garo Hills, Balpharam Nat. Park, 25.11N, 90.51E, E. Jendek \& O. Sausa 22-27.V.1996, 1 ex. (cH). Central Nepal, Chitwan, Roy. Nat. Park, Sauraha vill., 27.35N, 84.30E, D. Kral 21-27.VII.2000, 1 ex. (cB); Nepal. Terai, Sauraha-Chitwan, J. Moravec 20-25.V.1992, 1 ex. (cB).

Distribution: This species is known from Sri Lanka, India, Nepal, Myanmar, Malaysia, Philippines, Vietnam, Borneo, Taiwan (Bordoni, 2002).

\section{Phacophallus japonicus (CAMERon, 1933)}

Examined material: Vietnam, Hanoi. J. Jendek 20-30. IV.1991, 1 ex. (NHMB); 100 km S Hanoi, Cuc Phuong Nat. Park, Jendek 2-12.V.1991, 1 ex. (NHMB). Central Laos, Khammouan prov., Nukai env., route n. 8 , $17^{\circ} .42^{\prime} 8^{\prime \prime N}, 105^{\circ} .08^{\prime}$ 9"E, $560 \mathrm{~m}$, Jendek \& Sausa, 1 ex. (cH). Malaysia, Tioman (Ins.), rd. Kampong Tekek-K. Juara, 2.48N, 104.11E, 400 m, D. Hauck 4-16.III.1998, 1 ex. (cH). W Sumatra, Talu, Simpangenpat, Sukaminanti, W. G. Ullrich VII.1992, 1 ex. (NHMB).

Distribution: This species is known from Thailand, Malaysia, Laos, Vietnam, Sumatra, Bali, Java, China (Bordoni, 2002), Myanmar (Bordoni, 2017).

\section{Phacophallus philippinus spec. nov. urn:Isid:zoobank.org:act:7175C0E0-77AD-4DBA-94FC-00FA79EE61FF (Figs 22-24)}

Examined material: Holotype $\sigma^{*}$ : Philippines, Mindanao, Lanao del Norte, Baloi env., C. Finetti VI. 2001 (cB).

Description: Length of body $3.8 \mathrm{~mm}$; from anterior margin of head to posterior margin of elytra: $2.3 \mathrm{~mm}$. A small, shiny Phacophallus, reddish brown, with darker head and yellowish brown elytra; antennae and legs brown. Head sub-rectangular, slightly narrow anteriad, with sub-rectilinear sides and largely rounded posterior angles. Eyes medium-sized and slightly protruding. Surface of head with deep, long ocular and frontal grooves, and with fine, very sparse punctation. Pronotum very dilated anteriad, with oblique anterior margins, largely rounded anterior angles and sinuate sides, longer than head, as wide as it in anterior portion. Surface with dorsal series of 5 punctures and lateral series of 4 punctures. Elytra broad, long, dilated posteriad, with rounded humeral angles. Surface wrinkled, with three series of very fine punctures, one juxtasutural, one median and one lateral. Abdomen without microsculpture, with fine, very scattered punctation.

Tergite and sternite of the male genital segment as in Figs 22-23. Aedeagus (Fig. 24) $1 \mathrm{~mm}$ long, of usual shape; inner sac short, covered with fine scales and spinulae, and with 4 short, robust spines in the middle portion.

Etymology: The specific epithet refers to Philippines.

Distribution: The species is known only from the type locality.

Remarks: This species differs from the congeners by the small size, shape of pronotum and by the structure of inner sac of the aedeagus. In the Philippines occurs Phacophallus pallidipennis (Мотschulsky, 1858) and P. flavipennis (KrAATZ, 1859) (Bordoni, 2002). 


\section{Erymus salgarii BoRDONI, 2002}

Examined material: Borneo, Sabah, Mt Kinabalu, Zhou 15.IV.2015, 5 exx. (cB).

Distribution: The species is very common on Mt Kinabalu in Sabah (Bordoni, 2004).

\section{Erymus gracilis (FAuveL, 1895)}

Examined material: Borneo, Sabah, Ranau, Poring. H. S., 500 m, Zhou 18.IV.2015, 8 exx. (cB).

Distribution: E. gracilis is known from the Caspian Area and widespread in the Oriental Region, from Sri Lanka to Sumba, and Taiwan (Bordoni, 2011). New record for Sabah. In Borneo occurs two other species, E. heumorphus Bordoni, 2002 from Kalimantan and E. bruneianus Bordoni, 2002 from Brunei, with very different aedeagus.

\section{Xanthophius filum (KRAATZ, 1859)}

(Fig. 34)

Examined material: Nepal, Terai, Sauraha-Chitwan, J. Moravec 20-25.V.1992, 1 ex. (NHMB). Assam, Kaziranga, 750 m, Wittmer \& Baroni Urbani 7-9.V.1976, 2 exx. (NHMB), 2 exx. (cB).

Vietnam, 100 km S Hanoi, Cuc Phong Nat. Park, Jendek 2-12.V.1991, 3 exx. (NHMB); same data, J. Strand 2-11.V.1991, 6 exx. (NHMB), 1 ex. (cB); S Vietnam, $40 \mathrm{~km}$ NW Ankhe, Buon Luoi, 620-750 m, 14.10N, 108.30E, Pacholatko \& Dembicky 28.III-12.IV.1995, 1 ex. (NHMB). Philippines, Kolambugao, 1 ex. (cB).

Distribution: This species is widespread in the Oriental Region (BORDONI, 2002).
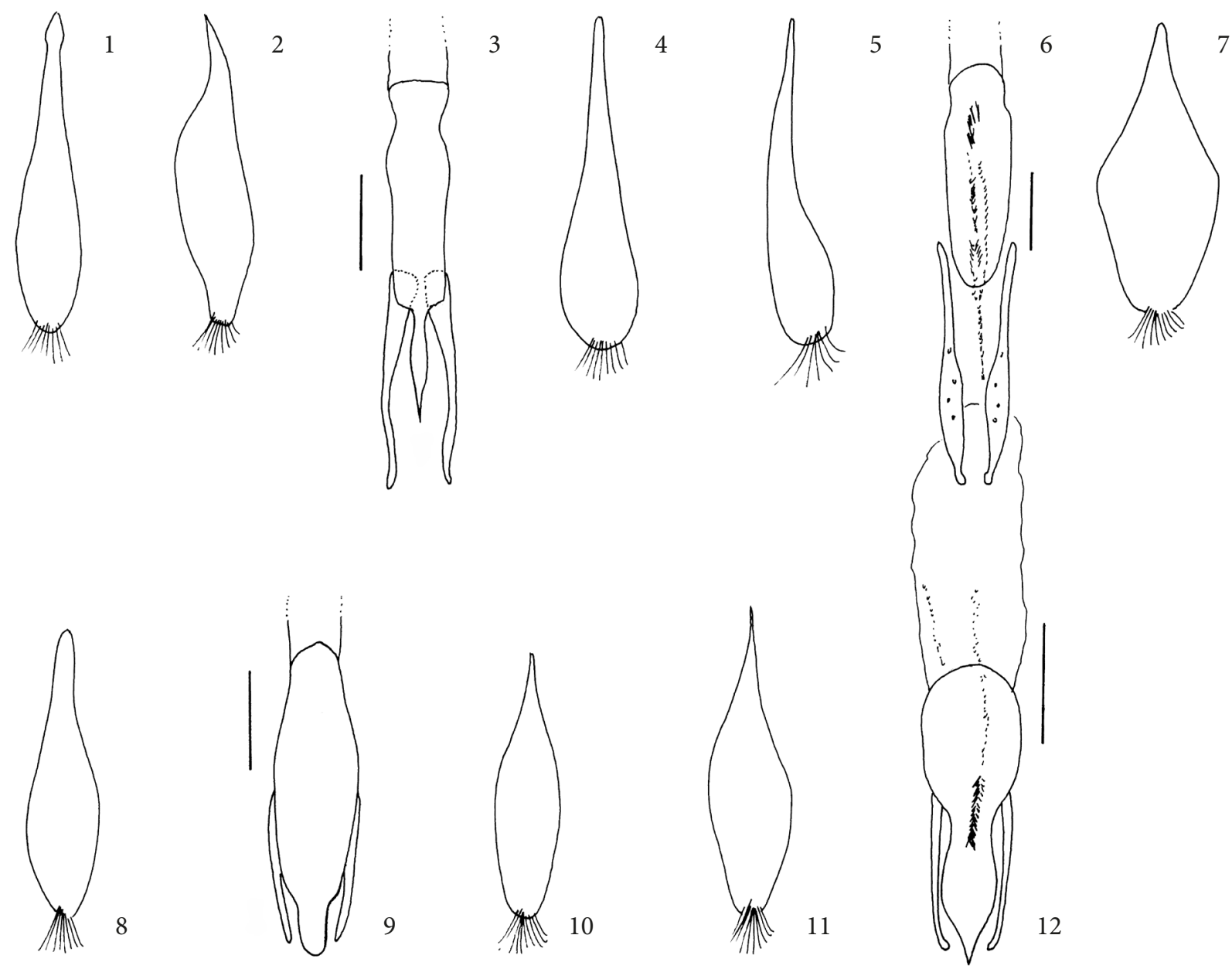

Figs 1-12: Tergite and sternite of the male genital segment and aedeagus of Pachycorynus sabahensis spec. nov. (1-3), P. balaneion spec. nov. (4-6), P. kinabaluensis spec. nov. (7-9) and P. danum spec. nov. (10-12) (scale bar: $0.1 \mathrm{~mm}$ ). 
Medhiama nepalica spec. nov.

urn:Isid:zoobank.org:act:B8C8F894-EC9B-4EC4-BE91-30D8AD412AB (Figs 25-27)

Examined material: Holotype $\sigma^{\star}$ : NE Nepal, Lukla, 2900 m, I. Zhou 15.VII.2016 (cB).

Description: Length of body $3.9 \mathrm{~mm}$; from anterior margin of head to posterior margin of elytra: $2.1 \mathrm{~mm}$.
Entirely dark reddish brown, with light brown antennae and legs; elytra and abdomen slightly paler. Head subrectangular, with slightly rounded sides and widely rounded posterior angles. Eyes medium-sized and slightly protruding. Surface shiny, with evident, sparse punctation, distinclty denser on lateral portions. Pronotum dilated anteriorly, longer than head and as wide as it in anterior portion, with slightly oblique anterior margins, rounded anterior angles and feebly sinuate sides. Surface
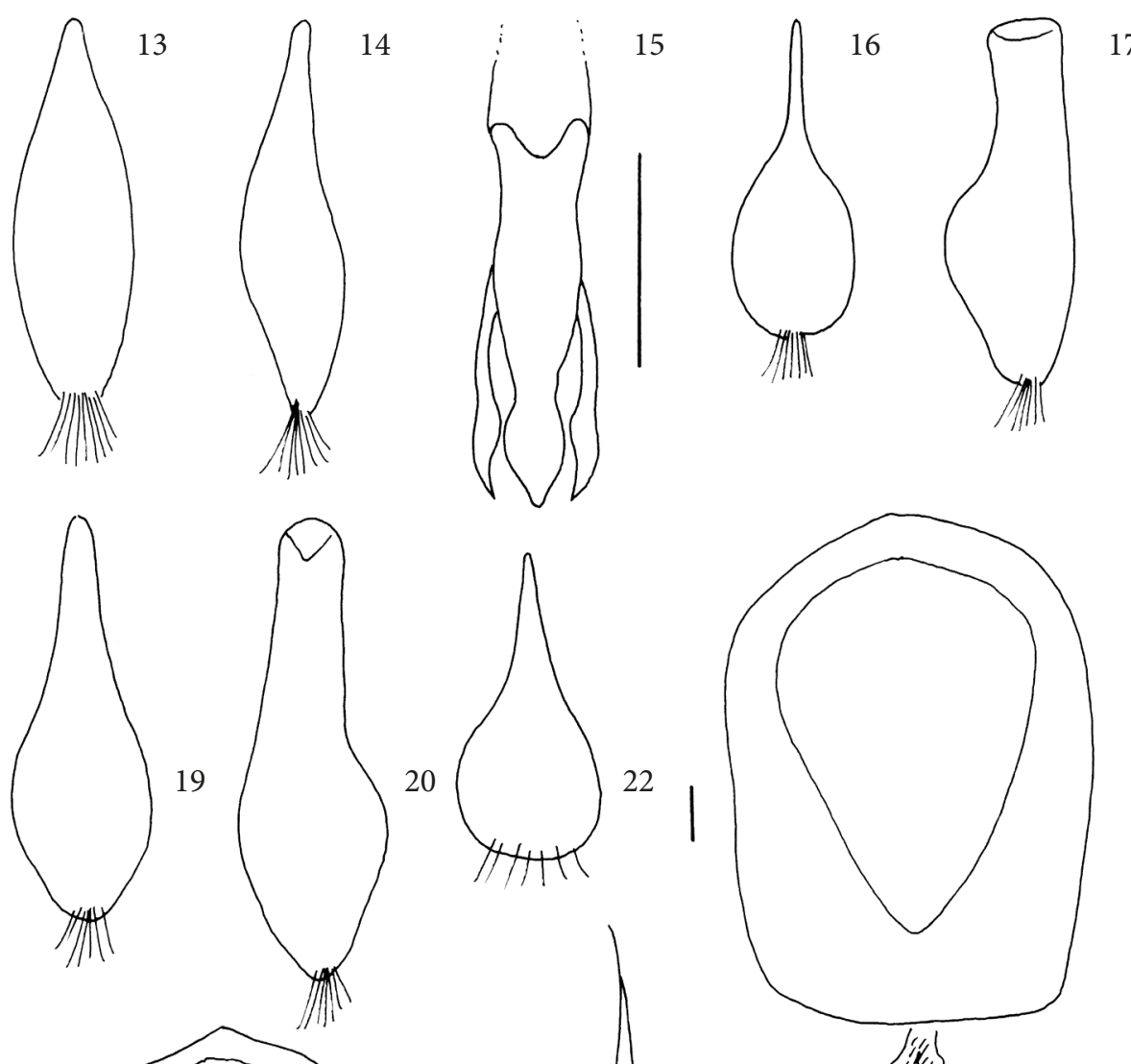

17
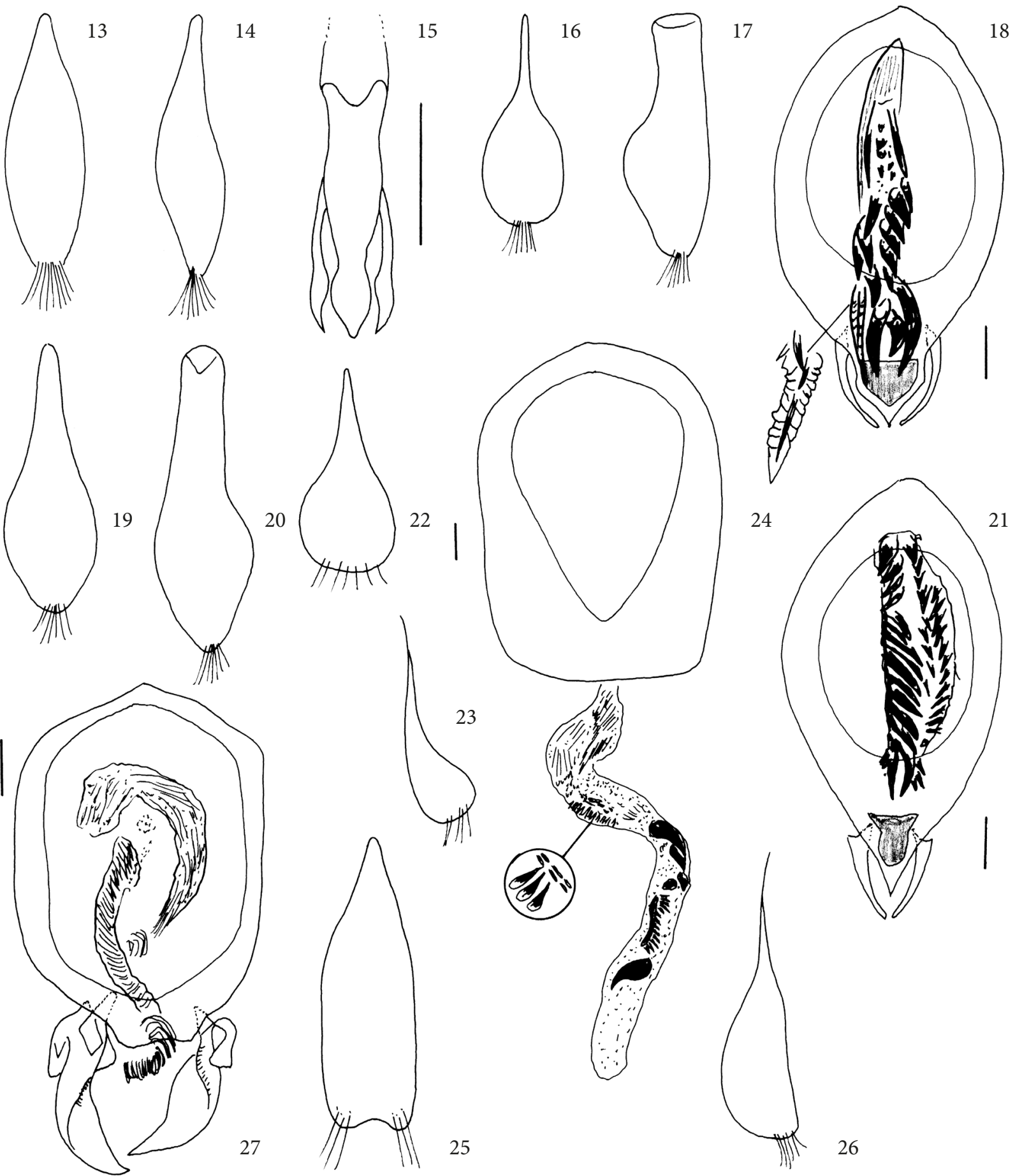

23

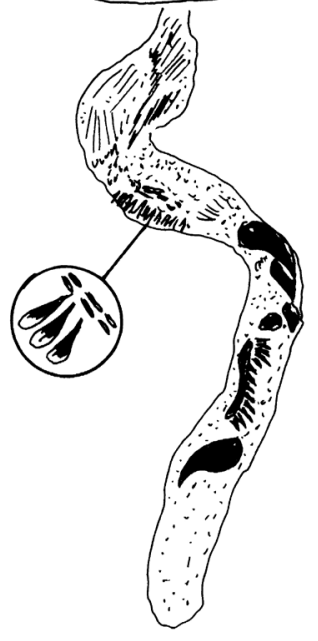

24
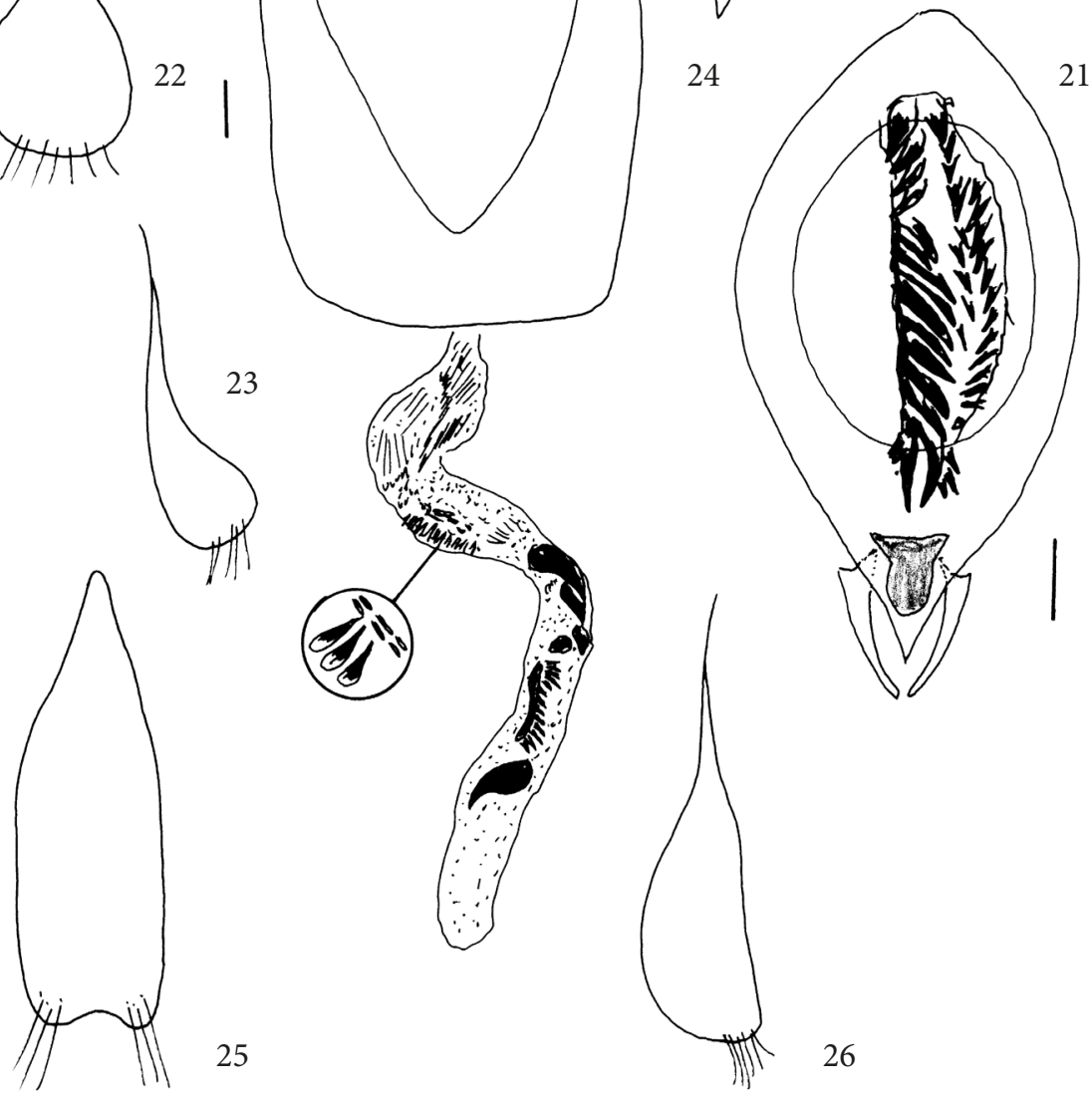

25

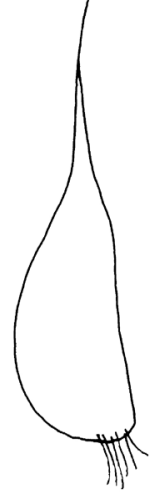

26

Figs 13-27: Tergite and sternite of the male genital segment and aedeagus of Pachycorynus lanceolatus spec. nov. (13-15), Metolinis vucanalis spec. nov. (16-18), Metolinis jubing spec. nov. (19-21) (scale bar: $0.1 \mathrm{~mm}$ ), Phacophallus philippinus spec. nov. (22-24), and Medhiama nepalica spec. nov. (25-27) (scale bar: $0.1 \mathrm{~mm}$ ). 


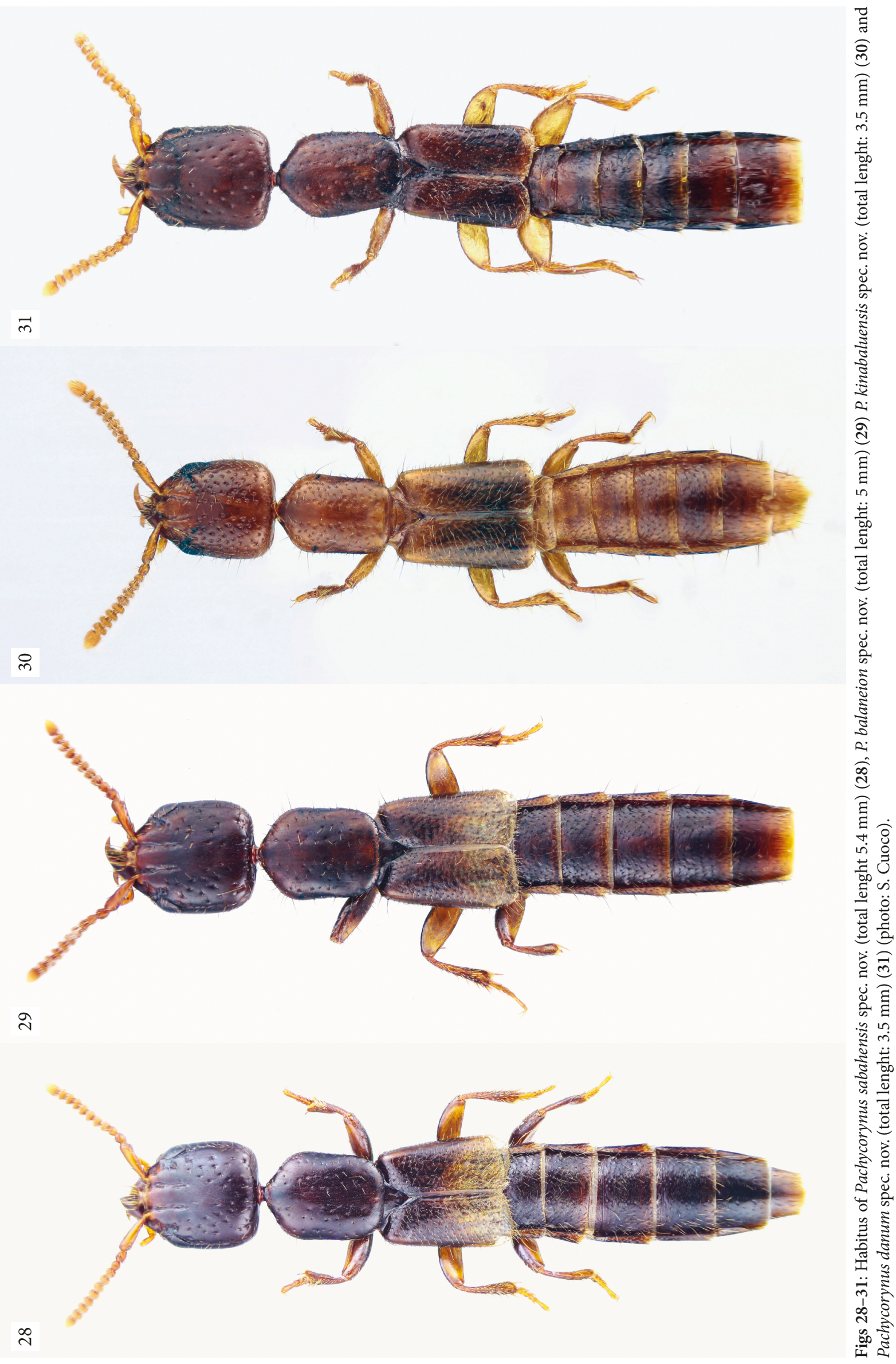




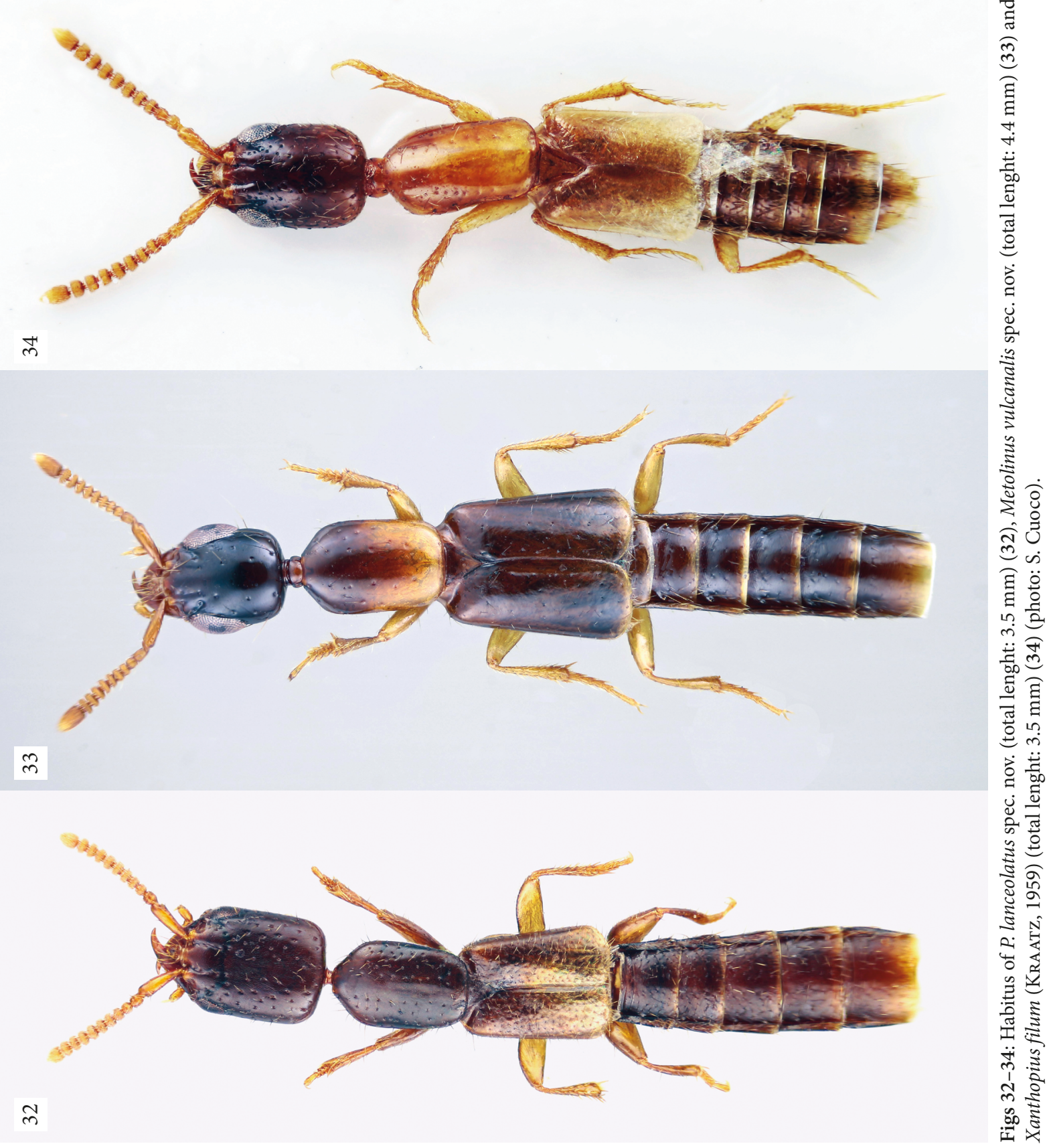

with dorsal series of 7 fine punctures and lateral series of 3-4 spaced punctures. Elytra longer and wider than pronotum, dilated posteriad, with conspicuous humeral angles. Surface with few series of fine, scattered punctation, especially on sides. Abdomen with fine, transverse micro-striation and fine, very spaced punctation.

Tergite and sternite of the male genital segment as in Figs 25-26. Aedeagus (Fig. 27) $0.92 \mathrm{~mm}$ long, sub-rectangular, broad, with asymmetric parameres; inner sac with long, distal tufts of arched, long spinulae, followed by 2 narrow areas covered with fine spinulae.

Etymology: The specific epithet refers to Nepal.
Distribution: The species is known only from the type locality.

Remarks: This is a very small Medhiama Bordoni, 2002. It differs from M. schawalleri BoRDONI, 2002 from Nepal (Myagdi Khola) by significantly smaller body, coloration, punctation of head and pronotum (punctation of $M$. shawalleri dense on the head and on sides of a median stripe of the pronotum), shape of parameres and inner sac. It differs also from M. pauper (ShARP, 1889) from Nepal, North India, China and Japan (Bordoni, 2002) by darker coloration, punctation and aedeagus with different parameres and inner sac. 


\section{Atopolinus ovaliceps (SCHEERPELTZ, 1965)}

Examined material: Malaysia, Cameron Higl., Tanahrata, Y. Kiyoyama 7.IV.1976, 2 exx. (cH); same data, Cameron Higl., de Rougemont 25-30.III.1984, 1 우 (cB).

Distribution: This species is known from Bhutan, Myanmar, Thailand, Malaysia and China (Bordoni, 2002).

\section{Acknowledgements}

I wish to thank the colleagues for providing the material to this study: M. Borer (Naturhistorisches Museum, Basel) and Y. Hayashi (Kawanishi). My thanks also to S. Cuoco (Livorno) for nice photographs.

\section{References}

Bordoni, A. 2002: Xantholinini della Regione Orientale (Coleoptera: Staphylinidae). Classificazione, Filogenesi e Revisione Tassonomica. Volume 33: Monografie di Museo Regionale di Scienze Naturali - Museo Regionale di Scienze Naturali, Torino: 998 pp. - ISBN 8886041454 - ihttp://Www.nhbs.com/1 xantholinini-della-regione-orientale-coleopterastaphylinidae-classificazione-fīogenesi-e-revisionetassonomica-xantholinini of the-oriental-col eoptera-staphylinidae-classification-phylogeny-and-1

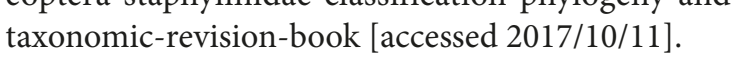

BorDonI, A. 2003 : Nưvi dati per la conoscenza degli Xantholinini della Regione Orientale III. Nuove specie del Naturhistorisches Museum di Vienna (Insecta Coleoptera Staphylinidae). - Quaderno di Studi e Notizie di Storia Naturale della Romagna 17 (suppl): 43-54.

Bordoni, A. 2004: New data on the Xantholinini of the Oriental Region. VIII. Species from Mount Kinabalu (Sabah) collected by Ales Smetana (Coleoptera, Staphylinidae). - Redia 87: 27-38. - hhttp://www.' redia.it/images/stories/pdf2004/06\%20bordoni.pdf [accessed 2017/11/08].
Bordoni, A. 2011: New data and records on Xantholinini of Taiwan collected by Ales Smetana, with description of new species (Coleoptera, Staphylinidae). = Redia 94: _ 25-33. _ _ _http://www.redia.it/images/stories/1

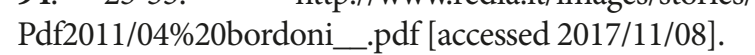

BorDONI, A. 2017: New data on the Oriental Xantholinini. 40. New species and new records in the collection of Tateo Ito, Kyoto (Coleoptera, Staphylinidae)._-Redia 100: 19-23. -DOI: http://dx.doi.org/10.19263/REDIA-100.17.03.

CAMERON, M. 1932: The Fauna of British India including Ceylon and Burma, Coleoptera. Staphylinidae. III. London, Taylor \& Francis: xiii + 443 pp.

Cameron, M. 1933: New species of Staphylinidae (Col.) from Japan. - The Entomologist's Montly Magazine 69: 168-175.

Coiffait, H. 1975: Xantholininae, Paederinae et Euasthetinae récoltés aiu Népal par le professeur Franz (Col. Staphylinidae). - Nouvelle Revue d'Entomologie 5(2): 153-186.

Coiffait, H. 1984: Contribution à la connaissance des Staphylinides de l'Himalaya (Coleoptera, Staphylinidae). - Annales de la Société Entomologique de France (n. s.), 20(4): 373-387.

KraAtz, G. 1859: Die Staphylinen-Fauna von Ostindien, insbesondere der Insel Ceylan. - Archiv der Naturgeschichte 25(1): 1-193.

Motschulsky, V. 1858: Enumération des nouvelles espèces des Coléoptères rapportés de ses voyages par M. Victor Motschulsky. - Bulletin de la Société Impérial des Naturalistes de Moscou 31(3): 204-264.

ScheERPELTZ, O. 1965: Wissenschaftliche Ergebnisse der Schwedischen Expedition 1934 nach Indien und Burma. Coleoptera Staphylinidae. - Arkiv för Zoologi 17(2): 93-371.

ShARP, D. 1889: The Staphylinidae of Japan. - The Annals and Magazine of Natural History 6(3): 249-267. 